\title{
EVALUATION OF SELF-EFFICACY DETERMINANTS IN COMMUNITY-DWELLING OLDER ADULTS WITH CHRONIC MUSCULOSKELETAL PAIN
}

\section{Avaliação dos fatores determinantes da autoeficácia em idosos da comunidade com dor crônica musculoesquelética}

\author{
Flavia Gonçalves Ziegler ${ }^{\mathrm{a}}\left(\mathbb{D}\right.$, Marcos Aparecido Sarria Cabrera ${ }^{\circledR}\left(\mathbb{C}\right.$, Aline Silva de Almeidab ${ }^{(0)}$, Thaisa

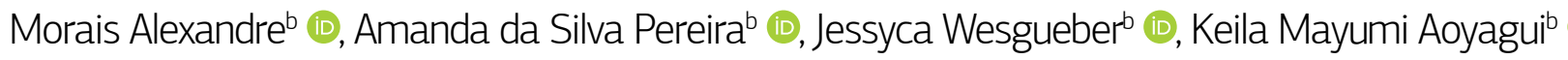

INTRODUCTION: Self-efficacy is defined as the strength of a person's convictions in being able to perform a given activity and obtain the expected result. It may act as a potent mediator between chronic musculoskeletal pain and how older adults cope with their disabilities. OBJECTIVE: To evaluate the determinants of self-efficacy beliefs and fear of physical exercise in community-dwelling older adults with chronic musculoskeletal pain. METHODS: This cross-sectional study recruited older adults with chronic musculoskeletal pain. Only individuals living in an urban area in southern Brazil and who reported pain for more than 3 months were included. A convenience sample was selected in a nonprobabilistic fashion. The study variables consisted of sociodemographic data; pain based on the Brief Pain Inventory and the Leeds Assessment of Neuropathic Symptoms and Signs for Patients with Chronic Pain; and self-efficacy based on the Chronic Pain Self-Efficacy Scale. Also, simple questions were created for physical exercise beliefs. For statistical analysis, absolute and relative frequency, $\chi^{2}$ test, and Mann-Whitney $U$ test were used as appropriate. RESULTS: The sample consisted of 193 older adults, mostly women with low level of education. Self-efficacy was best rated by older adults living alone and by those who were classified as exclusively nociceptive pain. CONCLUSION: Despite having chronic pain, older adults with higher self-efficacy feel confident in performing their tasks and have greater ability to cope with changes related to aging and to engage in self-care.

KEYWORDS: health services for the aged; self-efficacy; chronic pain.

INTRODUÇÃO: A autoeficácia pode ser definida como a força das convicções que se tem de poder executar determinada atividade obtendo o resultado esperado. Ela pode funcionar como potente mediador entre a dor crônica musculoesquelética e a maneira como o idoso lida com suas próprias incapacidades. OBJETIVO: Avaliar os fatores determinantes das crenças de autoeficácia e do medo do exercício em idosos da comunidade com dor crônica musculoesquelética. METODOLOGIA: Estudo transversal com idosos que sofrem de dor crônica musculoesquelética. Incluíram-se apenas indivíduos da área urbana que relataram dor há mais de três meses. Selecionou-se a amostra de forma não probabilística por conveniência. As variáveis estudadas basearam-se em dados sociodemográficos, na caracterização da dor pelo inventário breve de dor e pela escala Leeds Assessment of Neuropathic Symptoms and Signs (LANSS), na autoeficácia pela escala de autoeficácia para dor crônica e, para a crença sobre o exercício físico, elaboraram-se questões simples. Para as análises estatísticas aplicaram-se frequência absoluta e relativa, teste $\chi^{2}$ e teste de Mann-Whitney U quando pertinentes. RESULTADOS: A amostra compreendeu 193 idosos, em sua maioria mulheres com baixa escolaridade. A autoeficácia foi mais bem avaliada por idosos que moravam sós e por aqueles que foram classificados com dor exclusivamente nociceptiva. CONCLUSÃO: Ainda que possuam dores crônicas, idosos com melhor autoeficácia sentem-se confiantes na realização de suas tarefas e possuem melhor capacidade para o enfrentamento das mudanças relacionadas ao envelhecimento e para o autocuidado.

PALAVRAS-CHAVE: atenção à saúde do idoso; autoeficácia; dor crônica.

aniversidade Estadual de Londrina - Londrina (PR), Brazil.

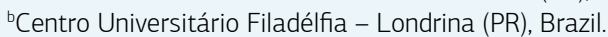

Correspondence data

Flavia Gonçalves Ziegler - Universidade Estadual de Londrina - Rua José Monteiro de Mello, 150 - Jardim do Lago - CEP: 86050-430 - Londrina (PR), Brasil. Email: flaviadafisio@gmail.com

Received on: 4/7/2020. Accepted on: 5/18/2020.

https://doi.org/10.5327/22447-212320202000039 


\section{INTRODUCTION}

Chronic pain has been continuously studied, classified, and coded so that health professionals know how to address the interference it produces in activities of daily living and emotional issues, such as depression, anguish, and anxiety, ${ }^{1}$ as it is considered a major factor leading to poor quality of life. ${ }^{2}$ Thus, some psychological factors, fear of movement, and even self-efficacy must be included in the assessment of chronic pain, given that individual prognosis is closely related to how the person copes with pain. ${ }^{3}$

Self-efficacy is defined as the strength of the convictions that a person has in being able to perform a given activity and obtain the expected result. ${ }^{4}$ It is not a matter of general beliefs about oneself, but actually of personal beliefs in specific situations. ${ }^{5}$ According to Martinez-Calderon et al., ${ }^{6}$ self-efficacy may act as a potent mediator between chronic musculoskeletal pain and established disability relationships, working as a protective factor.

Self-efficacy beliefs and ability to cope with the consequences of pain can be assessed using the Chronic Pain Self-Efficacy Scale. Created by Anderson in 1995, this measure was validated for Portuguese in $2004^{5}$ and has three domains: self-efficacy for pain management (PSE), self-efficacy for physical function (FSE), and self-efficacy for coping with symptoms (CSE).

The present study aimed to evaluate the determinants of self-efficacy beliefs and fear of physical exercise in community-dwelling older adults with chronic musculoskeletal pain.

\section{METHODS}

This exploratory, descriptive, cross-sectional study recruited older adults with chronic musculoskeletal pain living in the urban area of Londrina, Paraná, southern Brazil. Only individuals aged 60 years or over living in the urban area and who reported pain for more than 3 months were included.

A convenience sample was selected in a nonprobabilistic fashion, consisting of older adults who were scheduled to see an orthopedic specialist between April 2016 and April 2017. The sample size was calculated using as statistical parameters $95 \%$ confidence levels and maximum statistical errors of $5 \%$ for type I error and $20 \%$ for type II error, with sex, education, and monthly family income as variables of interest. The number of participants obtained was 193 older adults. Data were collected by the research project team from January 2018 to June 2019.

To characterize the sample, the following sociodemographic data were collected: sex (female or male), marital status (with or without a partner), age range (60-69 years or
70 years or over), obesity (defined as body mass index - BMI $\geq 30 \mathrm{~kg} / \mathrm{m}^{2}$ ), living alone (yes or no), smoking (yes or no), and use of nondrug therapy (therapeutic modality, weekly frequency, session duration, and follow-up period).

Two instruments were used to characterize the pain: the Brief Pain Inventory, which identifies the location, intensity, interference, and impact of pain on activities of daily living, ${ }^{7}$ as well as the drug therapies adopted; and the Leeds Assessment of Neuropathic Symptoms and Signs for Patients with Chronic Pain (LANSS), which is used to classify pain as nociceptive, neuropathic, or mixed.

To assess self-efficacy beliefs, a Portuguese language version of the Chronic Pain Self-Efficacy Scale was used, consisting of three domains: PSE, with five items, FSE, with nine items, and CSE, with eight items. Each item is scored from 10 to 100 on a Likert scale, and the final score ranges from 30 to 300 . The higher the score, the higher the self-efficacy belief. ${ }^{5,9}$ To assess some beliefs about pain as the main limitation for activities of daily living and about the influence of physical exercise to relieve or exacerbate pain, simple questions were created with dichotomous answers ("yes" or "no").

The database was tabulated in a Microsoft Excel spreadsheet and analyzed using SPSS for Windows, version 19.0 (IBM SPSS Inc. ${ }^{\odot}$, Chicago, Illinois, USA). For descriptive analysis, the distribution of absolute and relative frequencies was used; for bivariate analysis, the $\chi^{2}$ test was used; and for analysis of nonparametric data, the Mann-Whitney $U$ test was used, with distribution described by median and interquartile range.

This study was approved by the Human Research Ethics Committee at the Universidade Estadual de Londrina, with opinion no. 2.298.277, and by the National Research Ethics Commission at the Brazilian Ministry of Health, with Certificate of Presentation for Ethical Appreciation (CAAE) no. 72543917.2.0000.5231.

\section{RESULTS}

In total, 193 older adults with chronic musculoskeletal pain were interviewed. In the sample, 136 participants were female (70.50\%), 111 (57.50\%) were aged 60-69 years, 159 (82.40\%) had up to two minimum wages of family income, and 117 (60.60\%) had incomplete primary education. Twenty-nine (15\%) participants lived alone, while 172 (89.10\%) participants reported having received some prescribed nondrug therapy for chronic pain. Regarding the characteristics of pain, the most frequent location was the knee (77.70\%), followed by the lower back (48.20\%). Exclusively nociceptive pain was identified in $54.90 \%$ of participants. 
For overall self-efficacy, no differences were found between the age ranges; however, there was a statistical difference in the CSE domain $(\mathrm{p}<0.01)$, with a more positive result for older adults aged 70 years or over. Furthermore, living alone was significantly associated with overall self-efficacy as well as with the other domains (PSE, FSE, and CSE) (Table 1). Regarding pain location, not having shoulder pain favored the participants' perceived PSE, FSE, and overall self-efficacy (103.16; $\mathrm{p}<0.02)$. Older adults who did not report knee pain had higher CSE (112.83; $\mathrm{p}<0.03)$ (Table 1). Older adults who reported exclusively nociceptive pain showed a statistically significant difference for higher perceived self-efficacy in all domains compared to those who had mixed or neuropathic pain.
Regarding the analysis of some beliefs, older adults who did not believe in pain as the main reason for their daily limitations had higher CSE $(p<0.01)$. Those who reported not being afraid of injury during exercise had higher FSE $(p<0.01)$ and overall self-efficacy $(p<0.05)$ (Table 1).

\section{DISCUSSION}

In the present study, self-efficacy was best rated by older adults living alone, by those aged 70 years or over (for CSE), and by those who were classified as exclusively nociceptive pain. No significant differences were found in self-efficacy beliefs when associated with sex, which is consistent with the results

Table 1 Self-efficacy in older adults with chronic musculoskeletal pain according to sociodemographic variables, obesity, therapies used, pain characteristics, professional characteristics, and beliefs about physical exercise.

\begin{tabular}{|c|c|c|c|c|c|c|c|c|}
\hline \multirow{3}{*}{ Variable } & \multicolumn{2}{|c|}{$\begin{array}{l}\text { Self-efficacy for } \\
\text { pain management }\end{array}$} & \multicolumn{2}{|c|}{$\begin{array}{l}\text { Self-efficacy for } \\
\text { physical function }\end{array}$} & \multicolumn{2}{|c|}{$\begin{array}{l}\text { Self-efficacy for } \\
\text { coping with symptoms }\end{array}$} & \multicolumn{2}{|c|}{$\begin{array}{c}\text { Overall } \\
\text { self-efficacy }\end{array}$} \\
\hline & $\begin{array}{l}\text { Median } \\
\text { (IQR) }\end{array}$ & p-value & \begin{tabular}{c||} 
Median \\
(IQR)
\end{tabular} & p-value & \begin{tabular}{c|} 
Median \\
(IQR)
\end{tabular} & $\mathrm{p}$-value & $\begin{array}{l}\text { Median } \\
\text { (IQR) }\end{array}$ & p-value \\
\hline & $\begin{array}{c}60.20 \\
(47.25-75.60)\end{array}$ & & $\begin{array}{c}56.00 \\
(43.00-74.00) \\
\end{array}$ & & $\begin{array}{c}65.00 \\
(51.25-79.37) \\
\end{array}$ & & $\begin{array}{c}182.20 \\
(146.85-221.60) \\
\end{array}$ & \\
\hline Sex & & 0.18 & & 0.36 & & 0.48 & & 0.44 \\
\hline Female & 93.56 & & 94.63 & & 98.82 & & 95.01 & \\
\hline Male & 105.20 & & 102.66 & & 92.66 & & 101.74 & \\
\hline Age range & & 0.75 & & 0.96 & & 0.01 & & 0.36 \\
\hline 60-69 years & 95.91 & & 96.84 & & 88.74 & & 93.84 & \\
\hline 70 or over & 98.48 & & 97.21 & & 108.18 & & 101.27 & \\
\hline Lives alone & & 0.06 & & 0.03 & & 0.04 & & 0.01 \\
\hline Yes & 114.78 & & 116.90 & & 116.10 & & 121.16 & \\
\hline No & 93.86 & & 93.48 & & 93.62 & & 92.73 & \\
\hline $\begin{array}{l}\text { Obesity (BMl } 330 \mathrm{~kg} / \\
\mathrm{m}^{2} \text { ) }\end{array}$ & & 0.17 & & 0.86 & & 0.22 & & 0.28 \\
\hline Yes & 101.52 & & 97.58 & & 101.03 & & 100.56 & \\
\hline No & 90.47 & & 96.16 & & 91.19 & & 91.86 & \\
\hline Drug therapy & & 0.51 & & 0.05 & & 0.89 & & 0.36 \\
\hline Yes & 98.22 & & 100.60 & & 97.25 & & 98.68 & \\
\hline No & 91.28 & & 80.18 & & 95.81 & & 89.16 & \\
\hline Nondrug therapy & & 0.06 & & 0.47 & & 0.87 & & 0.84 \\
\hline Yes & 100.81 & & 102.59 & & 98.23 & & 95.48 & \\
\hline No & 82.87 & & 95.49 & & 96.67 & & 97.41 & \\
\hline \multicolumn{9}{|l|}{ Pain location } \\
\hline Shoulder & & 0.04 & & 0.05 & & 0.28 & & 0.02 \\
\hline Yes & 84.71 & & 85.66 & & 90.53 & & 83.35 & \\
\hline No & 102.55 & & 102.12 & & 99.92 & & 103.16 & \\
\hline
\end{tabular}


Table 1 Continuation.

\begin{tabular}{|c|c|c|c|c|c|c|c|c|}
\hline \multirow{2}{*}{ Variable } & \multicolumn{2}{|c|}{$\begin{array}{l}\text { Self-efficacy for } \\
\text { pain management }\end{array}$} & \multicolumn{2}{|c|}{$\begin{array}{l}\text { Self-efficacy for } \\
\text { physical function }\end{array}$} & \multicolumn{2}{|c|}{$\begin{array}{c}\text { Self-efficacy for } \\
\text { coping with symptoms }\end{array}$} & \multicolumn{2}{|c|}{$\begin{array}{c}\text { Overall } \\
\text { self-efficacy }\end{array}$} \\
\hline & $\begin{array}{l}\text { Median } \\
\text { (IQR) }\end{array}$ & p-value & $\begin{array}{l}\text { Median } \\
\text { (IQR) }\end{array}$ & p-value & $\begin{array}{l}\text { Median } \\
\text { (IQR) }\end{array}$ & p-value & $\begin{array}{l}\text { Median } \\
\text { (IQR) }\end{array}$ & p-value \\
\hline Lower back & & 0.60 & & 0.48 & & 0.87 & & 0.44 \\
\hline Yes & 94.81 & & 94.08 & & 96.40 & & 93.81 & \\
\hline No & 99.04 & & 99.72 & & 97.65 & & 99.97 & \\
\hline Hip & & 0.71 & & 0.76 & & 0.65 & & 0.95 \\
\hline Yes & 99.16 & & 95.20 & & 99.66 & & 96.66 & \\
\hline No & 96.00 & & 97.83 & & 95.77 & & 97.16 & \\
\hline Knee & & 0.18 & & 0.63 & & 0.03 & & 0.19 \\
\hline Yes & 94.15 & & 95.96 & & 92.46 & & 94.19 & \\
\hline No & 106.95 & & 100.62 & & 112.83 & & 106.80 & \\
\hline \multicolumn{9}{|l|}{ Pain type } \\
\hline $\begin{array}{l}\text { Exclusively } \\
\text { nociceptive }\end{array}$ & & 0.01 & & 0.01 & & 0.05 & & 0.01 \\
\hline Yes & 106.03 & & 107.8 & & 104.11 & & 107.98 & \\
\hline No & 86.00 & & 84.36 & & 88.33 & & 83.63 & \\
\hline \multicolumn{9}{|l|}{ Beliefs } \\
\hline $\begin{array}{l}\text { Pain as main reason } \\
\text { for daily limitations }\end{array}$ & & 0.18 & & 0.16 & & 0.01 & & 0.06 \\
\hline Yes & 95.30 & & 95.22 & & 93.86 & & 94.65 & \\
\hline No & 113.56 & & 114.33 & & 127.53 & & 119.83 & \\
\hline $\begin{array}{l}\text { Fear that exercise } \\
\text { could hurt them }\end{array}$ & & 0.09 & & 0.01 & & 0.48 & & 0.05 \\
\hline Yes & 87.91 & & 84.22 & & 93.21 & & 86.59 & \\
\hline No & 102.06 & & 104.11 & & 99.11 & & 102.79 & \\
\hline $\begin{array}{l}\text { Exercise ever made } \\
\text { the pain worse }\end{array}$ & & 0.57 & & 0.04 & & 0.31 & & 0.21 \\
\hline Yes & 94.08 & & 86.36 & & 91.74 & & 90.56 & \\
\hline No & 98.74 & & 103.33 & & 100.13 & & 100.83 & \\
\hline
\end{tabular}

BMI: body mass index; IQR: interquartile range.

reported by Larsson et al., ${ }^{10}$ who also found no differences between men and women in the analysis of beliefs related to fear of movement. This demonstrates that sex is not the main variable interfering with self-efficacy in those individuals.

Furthermore, older adults aged 70 years or over had higher perceived CSE compared to those aged 60-69 years, which may be explained by the fact that some older adults expect, as a result of aging, pain and movement limitations and, therefore, create mechanisms to cope with these conditions, either by using medications or ignoring their own pain. ${ }^{11}$ In this stage, psychosocial resources are important for assisting the acquisition of adaptive behaviors and improving perceived self-efficacy. ${ }^{12}$
Older adults living alone showed a significant difference for higher perceived self-efficacy compared to those living with other people. According to Toledano-González et al., ${ }^{13}$ individuals have higher perceived self-efficacy and well-being when they are able to perform their activities of daily living independently. Thus, variables such as cognition and social support are important for coping with pain, ${ }^{13}$ and even though they live alone, these older adults possibly have such characteristics preserved.

The present study showed that older adults with shoulder pain have lower perceived self-efficacy compared to those with pain in other body regions, i.e., they feel less able to control their pain and perform activities of daily living. This finding is consistent with those of a study conducted by Imagama et al., ${ }^{14}$ in 
which shoulder pain had a greater negative impact on related domains of quality of life and mental health compared to other types of chronic musculoskeletal pain.

Musculoskeletal pain mostly has a nociceptive origin but it may also derive from neuropathic conditions. ${ }^{15}$ Although both types compromise the individual's physical and psychological health, the present study found that older adults with exclusively nociceptive pain obtained higher self-efficacy than those with mixed or neuropathic pain. According to Haythornthwaite and Benrud-Larson, ${ }^{16}$ suffering and intensity associated with both nociceptive and neuropathic pain are similar. However, according to Daniel et al., ${ }^{17}$ differences between neuropathic and nociceptive pain are found not only in the most common variables of pain assessment, such as mood, cognition, and physical function, but also in factors related to beliefs, pain experience, and emotions, which are even more evident for individuals with neuropathic pain.

In the present study, older adults who believed that pain was the main reason for limitations in their daily living, those who were afraid that exercise could hurt them, and those who believed that exercise ever made their pain worse had a statistical difference for lower self-efficacy in at least one domain. Thus, the fear that movement will make pain worse or aggravate an established injury makes many individuals believe that some activities cannot be performed. ${ }^{18,19}$

Overall, when individuals perceive pain as a threat and have catastrophic thoughts about it, they tend to behave in a way to avoid it. ${ }^{20}$ This belief is associated with disuse and poor physical function for daily living, ${ }^{21,22}$ which then induces the person to social isolation. ${ }^{23}$

Despite the relevance of cross-sectional studies, they have some limitations. In this study, one limitation is the inability to establish the cause-effect relationship between chronic pain and self-efficacy in the older adults. A second limitation is that although validated instruments were used to assess chronic pain and self-efficacy, the subjective nature of these variables might be more properly addressed by studies using a qualitative approach.

\section{CONCLUSION}

In this study, older adults reporting higher self-efficacy were those who lived alone and those who had exclusively nociceptive pain. The results bring to light the relevance of the ability to cope with changes related to aging and to engage in self-care, as those older adults feel confident in performing their tasks despite having chronic pain. Additionally, the importance of a multidisciplinary approach for the management of chronic pain is reinforced in order to ensure the autonomy, independence, and well-being of those individuals.

\section{ACKNOWLEDGMENTS}

We gratefully thank the older participants of the study as well as the students at Centro Universitário Filadélfia who were members of the research group.

\section{CONFLICT OF INTEREST}

There is no conflict of interest to disclose.

\section{FUNDING}

This study was funded by the authors.

\section{AUTHOR 'S CONTRIBUTION}

FGZ: study design, data analysis and interpretation; elaboration of intellectual content, approval of the final version, agreement to be responsible for all of the aspects of the study. MASC: study design, data analysis and interpretation, elaboration of intellectual content, approval of the final version. AA: data collection. TA: data collection. AP: data collection. JW: data collection. KA: data collection.

\section{REFERENCES}

1. Nicholas M, Vlaeyen JWS, Rief W, Barke A, Aziz Q, Benoliel R, et al. The IASP classification of chronic pain for ICD-11: chronic primary pain. Pain. 2019;160(1):28-37. https://doi.org/10.1097/j.pain.0000000000001390

2. Treede RD, Rief W, Barke A, Aziz Q, Bennett MI, Benoliel R, et al. Chronic pain as a symptom or a disease: the IASP Classification of Chronic Pain for the International Classification of Diseases (ICD-11). Pain. 2019;160(1):19-27. https://doi.org/10.1097/j.pain.0000000000001384

3. Sleijser-Koehorst MLS, Bijker L, Cuijpers P, Scholten-Peeters GGM, Coppieters MW. Preferred self-administered questionnaires to assess fear of movement, coping, self-efficacy, and catastrophizing in patients with musculoskeletal pain —A modified Delphi study. Pain. 2019;160(3):600-6. https://doi.org/10.1097/j.pain.0000000000001441

4. Bandura A. Self-efficacy: toward a unifying theory of behavioral change. Adv Rehab Res Ther. 1978;1(1):139-61. https:/www.sciencedirect. com/science/article/abs/pii/0146640278900024?via\%3Dihub

5. Salvetti MG. Crença de autoeficácia e validação da "chronic pain self-efficacy scale" [dissertation]. São Paulo: Escola de Enfermagem da Universidade de São Paulo; 2004. 
6. Martinez-Calderon JPT, Zamora-Campos C, Navarro-Ledesma S, Luque-Suarez A. The Role of Self-Efficacy on the Prognosis of Chronic Musculoskeletal Pain: a Systematic Review. J Pain. 2018;19(1):10-34. https://doi.org/10.1016/j.jpain.2017.08.008

7. Ferreira KA, Teixeira MJ, Mendonza TR, Cleeland CS. Validation of brief pain inventory to Brazilian patients with pain. Support Care Cancer. 2011;19(4):505-11. https://doi.org/10.1007/s00520010-0844-7

8. Schestatsky P, Félix-Torres V, Chaves MLF, Câmara-Ehlers B, Mucenic T, Caumo W, et al. Brazilian Portuguese Validation of the Leeds Assessment of Neuropathic Symptoms and Signs for Patients with Chronic Pain. Pain Med. 2011;12(10):1544-50. https://doi.org/10.1111/j.15264637.2011.01221.x

9. Anderson KO, Dowds BN, Pelletz RE, Edwards WT, Peeters-Asdourian C. Development and initial validation of a scale to measure self-efficacy beliefs in patients with chronic pain. Pain. 1995;63(1):77-84. https:// doi.org/10.1016/0304-3959(95)00021-j

10. Larsson C, Hansson EE, Sundquist K, Jakobsson U. Chronic pain in older adults: prevalence, incidence, and risk factors. Scand J Rheumatol. 2017;46(4):317-25. https://doi.org/10.1080/030097 42.2016 .1218543

11. Larsson C, Hansson EE, Sundquist K, Jakobsson U. Kinesiophobia and its relation to pain characteristics and cognitive affective variables in older adults with chronic pain. BMC Geriatr [Internet]. 2016 [Accessed in 12 fev. 2020];16:128. Available in: https://www.ncbi.nlm.nih.gov/pmc/articles/PMC4936054 https://dx.doi.org/10.1186\%2Fs12877-016-0302-6

12. Sargent-Cox KA, Butterworth P, Anstey KJ. Successful Aging. Role of Physical Activity in the Relationship Between Mastery and Functional Health. Gerontologist. 2015;55(1):120-31. https://doi.org/10.1093/ geront/gnu042

13. Toledano-González A, Labajos-Manzanares T, Romero-Ayuso D. WellBeing, Self-Efficacy and Independence in older adults: A Randomized Trial of Occupational Therapy. Arch Gerontol Geriat [Internet]. 2019 [Accessed on Feb. 10, 2020];83:277-84. Available in: https://www. sciencedirect.com/science/article/abs/pii/S0167494319301104 https://doi.org/10.1016/j.archger.2019.05.002

14. Imagama S, Ando K, Kobayashi K, Seki T, Hamada T, Machino M, et al. Shoulder pain has most impact on poor quality of life among various types of musculoskeletal pain in middle-aged and elderly people: Yakumo study. Modern Rheumatology [Internet]. 2020 [Accessed on Feb. 7, 2020];30(3):568-72. Available in: https://www.tandfonline. com/doi/abs/10.1080/14397595.2019.1623364

https://doi.org/10.1080/14397595.2019.1623364

15. Blyth FM, Noguchi N. Chronic musculoskeletal pain and its impact on older people. Best Pract Res Clin Rheumatol. 2017;31(2):160-8. https://doi.org/10.1016/j.berh.2017.10.004

16. Haythornthwaite JA, Benrud-Larson LM. Psychological aspects of neuropathic pain. Clinl J Pain. 2000;16(2 Supl.):S101-5. https://doi. org/10.1097/00002508-200006001-00017

17. Daniel HC, Narewska J, Serpell M, Hoggart B, Johnson R, Rice ASC Comparison of psychological and physical function in neuropathic pain and nociceptive pain: Implications for cognitive behavioral pain management programs. Eur J Pain. 2008;12(6):731-41. https://doi. org/10.1016/j.ejpain.2007.11.006

18. Crombrez G, Vervaet L, Lysens LVR, Baeyens F, Eelen FBP. Avoidance confrontation of painful, back-straining movements in chronic back pain patients. Behav Modif. 1998;22(1):62-77. https://doi. org/10.1177/01454455980221004

19. Kori SH, Miller RP, Todd DD. Kinesiophobia: A new view of chronic pain behavior. Pain Manag. 1990;3:35-43.

20. Simons LE, Kaczynski K. The Fear Avoidance Model of Chronic Pain: Examination for pediatric application. J Pain. 2012;13(9):827-35. https://doi.org/10.1016/j.jpain.2012.05.002

21. Vlaeyen JWS, Linton SJ. Fear-avoidance and its consequences in chronic musculoskeletal pain: a state of the art. Pain. 2000;85(3):317-32. https://doi.org/10.1016/s0304-3959(99)00242-0

22. Leeuw M, Goossens MJB, Linton SJ, Crombez G, Boersma K, Vlaeyen JWS. The Fear-Avoidance Model of Musculoskeletal Pain: Current State of Scientific Evidence. J Behav Med. 2007;30(1):77-94. https:// doi.org/10.1007/s10865-006-9085-0

23. Ferrari S, Vanti C, Pellizzer M, Dozza L, Monticone M, Pillastrin P. Is there a relationship between self-efficacy, disability, pain and sociodemographic characteristics in chronic low back pain? A multicenter retrospective analysis. Arch Physiother [Internet]. 2019 [Accessed on Feb. 7, 2020];9:9. Available in: https://www.ncbi.nlm. nih.gov/pmc/articles/PMC6790029/pdf/40945 2019_Article_61.pdf https://doi.org/10.1186/s40945-019-0061-8 